\title{
IDENTIFIKASI DAN KEANEKARAGAMAN JENIS IKAN DI SUNGAI TERAP KABUPATEN MERANGIN PROPINSI JAMBI.
}

\author{
Arpiagam, Rini Hertati, Budiyono
}

\begin{abstract}
ABSTRAK
Hasil Survey pendahuluan Sungai Terap berfungsi bagi masyarakat untuk : MCK, Irigasi, di 3 Stasiun lokasi penelitian menandakan bahwa ada beberapa jenis ikan seperti, Ikan Semah, Sebarau, Belida Tapah, Gabus dan jenis ekonomis penting lokal lainnya, telah sulit di temukan.

Tujuan penelitian ini adalah : 1). Identifikasi jenis ikan yang tertangkap di wilayah Sungai Terap. 2). Analisis Indeks Keanekaragaman jenis ikan, Kepadatan Populasi, Kepadatan Relatif dan Frekuensi Kehadiran.

Penelitian dan pengamatan pada bulan Mei-November 2016. Pemilihan stasiun pengamatan secara terpilih (purposive sampling).

Hasil Penelitian terdapat 21 jenis dari 4 Ordo 7 Famili dan 13 Genus dari ikan yang berhasil di kumpulkan berjumlah 817 dengan menggunakan tiga Alat tangkap, yaitu: Jaring Insang (Gillnet), Jala Lempar (Filling gear), dan Tembak Ikan atau sering disebut Senapan Ikan.

Kepadatan Populasi tertinggi ditemukan 4 Jenis Ikan diantaranya adalah : Seperas Puntius tawerensis(n.sp) sebesar 0,018000 (individu) $/ \mathbf{m}^{2}$, Baung Macrones nemurus (C.V.) sebesar 0,010714 (individu) / $\mathbf{m}^{2}$, Batu, Siben Choerodon oligantus (Blkr) sebesar 0,013000(individu) / $\mathbf{m}^{2}$, kemudian disusul oleh jenis Ikan Lanli,Leungli Botia hymenophysa (Blkr) sebesar 0,012200 (individu).

Untuk Kepadatan Relatif paling tinggi terdapat pada ikan Seperas Puntius tawerensis(n. sp) sebesar 0,18\% Frekuensi Kehadiran tertinggi yakni : Seperas Puntius tawerensis(n.sp) Baung Macrones nemurus (C.V.), Batu, Siben Choerodon oligantus (Blkr) Lanli,Leungli Botia hymenophysa (Blkr), dan 17 jenis ikan lainnya masing - masing 39\%. Sebaliknya Frekuensi Kehadiran terendah di temukan pada beberapa jenis ikan yaitu, Baung Murai / Hinur Ikan Tali-tali, Acanthopthalmus Kuhli $(C V)$.
\end{abstract}

\section{Pendahuluan}

Indonesia merupakan Negara kepulauan dengan tingkat biodiversitas tertinggi setelah Brazil. Secara geografis wilayah Indonesia berada di antara dua samudra, yaitu samudra hindia dan pasifik sehingga membuat keanekaragaman hayati melimpah. Keanekaragaman ikan di Indonesia sangat banyak, berdasarkan LIPI (2010) diperkirakan terdapat 4000- 6000 jenis ikan di seluruh perairan Indonesia. Di Asia tenggara terdapat 2917 jenis ikan 
SEMAH : Journal Pengelolaan Sumberdaya Perairan VOL. 1 No. 2

Desember 2017

tawar yang teridentifikasi (Kottelat et al 1993).

Sungai Terap adalah salah satu sungai yang terdapat di Kabupaten Merangin Propinsi Jambi, selain Sungai Merangin, dan Batang Mesumai, Tembesi, dan Batang Tabir serta Subsub Das yang lainnya. Sungai terap mempunyai Panjang lebih kurang 30.000 meter $(30 \mathrm{~km})$ dengan lebar kurang lebih 10-20 meter. Sungai Terap Berhulu di daerah pengunungan, di Gunung Masurai. Dalam hubungannya dengan Sungai Batanghari Sungai Terap merupakan Sub-Sub (DAS) Sungai Batanghari.

Berdasarkan hasil Survey pendahuluan penulis, Sungai Terap dan anak sungai asosiasinya berperan sentral bagi masyarakat setempat dan telah dimanfaatkan diantaranya untuk : MCK, irigasi, transportasi, Penangkapan ikan, dan pembuangan limbah nilam. Disamping itu disekitar Sungai dan sub-sub DAS terdapat pula aktifitas sebagai berikut : Perkebunan Sawit, Karet, nilam dan Kopi milik warga, Pembuangan sampah atau limbah rumah tangga, Pembangkit Listrik Tenaga Air (PLTA), dan Penebangan hutan.

Hasil wawancara yang dilakukan dalam survey pendahuluan penulis dengan nelayan dilokasi penelitian, beberapa jenis ikan seperti, Ikan Semah, Sebarau, Belida Tapah dan jenis ikan ekonomis penting lokal lainnya, telah sulit ditemukan. Degan demikian suatu pada masa yang akan mendatang sakan mengalami hilangnya suatu mata rantai alam atau warisan untuk generasi yang akan datang.

Tujuan penelitian ini adalah untuk mengetahui jenis-jenis ikan yang tertangkap di Sungai Terap dan untuk mengetahui Indeks Keanekaragaman jenis ikan, Kepadatan Populasi,
ojs.umb-bungo.ac.id/index-php/SEMAHJPSP

ISSN : 2580-0736

Kepadatan Relatif dan Frekuensi Kehadiran.

\section{Metodologi Penelitian}

Penelitian ini dilaksanakan pada Bulan Mei sampai November 2016. Penelitian ini dilakukan di Sungai Terap, Kabupaten Merangin Provinsi Jambi. untuk mengetahui jenis ikan yang diteliti dilakukan penangkapan ikan pada 3 stasiun yang telah ditentukan.

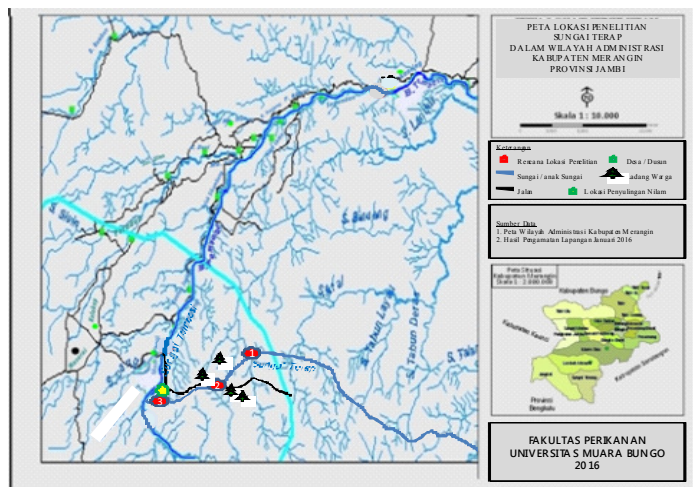

Lokasi Penelitian

Metode penentuan stasiun pengambilan sampel dilakukan dengan cara purposive sampling yaitu penentuan stasiun penelitian dilakukan berdasarkan tujuan dengan memperhatikan berbagai pertimbangan kondisi dan keadaan tempat penelitian atau karakteristik seperti kondisi dominan aktivitas penambangan pasir dan lain-lain.

Sampel ikan dari setiap stasiun ditangkap dengan menggunakan beberapa jenis alat tangkap antara lain : Jaring Insang tetap, Jala, dan Tembak atau sering disebut Senapan Ikan. Pengambilan sampel di lakukan 2-4 kali ulangan Pada setiap stasiunnya.

Identifikasi ikan dilakukan di Laboratorium Biologi Universitas Muara Bungo, dengan mengamati ciriciri morfologi pada ikan. Adapun proses identifikasi adalah sebagai berikut : 
SEMAH : Journal Pengelolaan Sumberdaya Perairan VOL. 1 No. 2

Desember 2017
ojs.umb-bungo.ac.id/index-php/SEMAHJPSP

ISSN : 2580-0736
Untuk menganalisis data yang diperoleh dari dilapangan digunakan beberapa metoda yaitu metode Analisis Indeks Keanekaragaman Jenis Ikan (Hi) dan Kepadatan Populasi, Kepadatan Relatif dan Frekuensi Kehadiran.

\section{Hasil dan Pembahasan}

1. Keanekaragaman Jenis Ikan

Hasil tangkapan selama penelitian pada 3 Stasiun ditemukan sebanyak 21 Jenis dari 4 Ordo 7 Famili dan 13 Genus, seperti tersaji dalam tabel 4.1. dibawah ini. Sedangkan menurut hasil wawancara lansung dengan petani / nelayan pada masing-masing Staiun di Sungai Terap ternyata selama dalam tahun 2012 telah ditemukan atau tertangkap nelayan sebanyak 39 jenis ikan atau 30\% dari ikan lokal air tawar Propinsi Jambi. Selanjutnya bila dibandingkan dengan hasil inventarisasi jenis-jenis ikan lokal air tawar Propinsi Jambi (Sudrajat, A. Et al, 2009) ditemukan sebanyak 131 Jenis Ikan, 25 Famili, 14 Ordo. Maka hasil tangkapan selama penelitian di tiga Stasiun Sungai Terap Kabupaten Merangin, baru 22,02\% dari jenis ikan yang tercatat di perairan tawar Propinsi Jambi. Adapun 21 jenis ikan tersebut dapat dilihat dalam Lampiran 3. Hasil penelitian ini lebih tinggi $2,02 \%$ dari pada Hasil penelitian Budiyono, 2010 di perairan Sungai Batang Bungo, dari 4 stasiun, 2 musim (musim hujan dan musim kemarau) yang menemukan 25 jenis ikan dari 16 genus dan 9 famili / $19,08 \%$ dari 131 jenis ikan di perairan tawar Propinsi Jambi. Secara umum jumlah jenis ikan pada lokasi penelitian relatif rendah jika dibandingkan dengan jenis ikan yang ada di perairan tawar Propinsi Jambi sebanyak 131 Jenis. Masih sedikitnya jumlah jenis hasil tangkapan selama penelitian ini di karenakan :

$>$ Waktu penelitian atau musim yang relatif singkat dan sedikit (hanya pada musim hujan).

$>$ Jumlah dan Jenis alat tangkap yang terbatas (hanya 3 alat tangkap).

$>$ Habitat ikan termasuk sungai bagian hulu dengan bentuk dasar sungai berbatu, sehingga jenis ikan yang ditemukan jenis - jenis ikan batu.

$>$ Kemungkinan telah terjadi penurunan jumlah populasi ikan di Sungai Terap Kabupaten Merangin Propinsi Jambi. Menurunnya jumlah populasi ikan di Sungai menyebabkan peluang tertangkapnya berbagai jenis ikan menjadi lebih kecil (Yustina dalam Afreni H, 2004).

$>$ Luas area dan daerah peangkapan yang terbatas $(7000 \mathrm{~m} /$ Stasiun $)$.

hal ini selaras dengan pendapat Watoon, dalam Budiyono, 2011, bahwa keanekaragaman jenis ikan sungai tergantung pada dua faktor. Pertama, peningkatan jumlah mikro habitat akan dapat meningkatkan keragaman. Kedua, area yang lebih luas sering memilki habitat yang lebih besar dibanding dengan area yang lebih sempit.

2. Nilai Keanekaragaman Jenis Ikan (Hi)

Menurut Soegianto dalam Muhammad J, Emiyarti dan Syamsul K, 2013, bahwa indeks keanekaragaman jenis (Hi) adalah indeks yang menunjukkan banyak tidaknya jenis dan individu yang ditemukan pada suatu perairan. Selanjutnya menurut Fachrul dalam Muhammad J, Emiyarti dan Syamsul K, 2013, menjelaskan bahawa indeks keanekaragaman (indeks of diversity) berguna dalam mempelajari 
SEMAH : Journal Pengelolaan Sumberdaya Perairan VOL. 1 No. 2

Desember 2017

gangguan faktor-faktor lingkungan (abiotik) terhadap suatu komunitas atau untuk mengetahui suksesi atau stabilitas suatu komunitas. Tujuan utama teori informasi Shannon-Wienner adalah untuk mengukur tingkat keteraturan dan ketidakteraturan dalam suatu sistem.

Nilai indeks Keanekaragaman Jenis Ikan (Hi) yang tertangkap selama penelitian di tiga Stasiun Sungai Terap berdasarkan Indeks Shannon dapat dilihat pada Tabel 4.1. berikut ini :
ojs.umb-bungo.ac.id/index-php/SEMAHJPSP

ISSN : 2580-0736

Tabel 4.1. Nilai Keanekaragaman Jenis Ikan (Hi) yang tertangkap selama penelitian di tiga Stasiun Penelitian di Sungai Terap Kabupaten Merangin.

\begin{tabular}{|c|c|c|c|c|}
\hline No & Tanggal & \multicolumn{3}{|c|}{ Nilai Indeks Keanekaragaman (Hi) } \\
\hline 1 & $11-07$ & $\begin{array}{c}\text { ST I } \\
\text { Juli }\end{array}$ & $\begin{array}{c}\text { ST II } \\
\text { Muara Pangi }\end{array}$ & $\begin{array}{c}\text { ST III } \\
\text { Muara Pangi Pangi }\end{array}$ \\
\cline { 3 - 5 } & 2016 & 2,4028 & 1,6687 & 1,1659 \\
\hline
\end{tabular}

Sumber : Data primer diambil bulan Juli 2016

Berdasarkan hasil perhitungan nilai Indeks Keanekaragaman pada Tabel 4.1 tersebut di atas, bahwa kisaran nilai Indeks Keanekaragaman jenis ikan (Hi) yang tertangkap selama penelitian di tiga Stasiun Sungai Terap yaitu 1,3 2,4. dimana Indeks tertinggi ditemui pada Stasiun I, Enam Kilo Meter dari Desa Muara Pangi ke arah Hulu Sungai Terap. Lebih tingginya nilai indeks keanekaragaman (Hi) dibanding Stasiun lain (Stasiun 2 dan 3) di karenakan Lokasi ini tidak terdapat Aktifitas Masyarakat seperti pembuangan sampah, Mandi, Cuci dan (MCK) serta penambangan pasir baik secara Modern maupun Tradisional.

Stasiun I. Masih banyak nya sumber makanan alami dari berbagai jenis tumbuhan yang berada di sekitar lingkungan yang bisa dimakan oleh ikan kemungkinan kualitas air di Stasiun ini masih dalam kondisi baik tanpa ada gangguan dari masyarakat setempat.

Stasiun II. Kemungkinan kualitas air di Stasiun ini menurun di karenakan terdapat beberapa aktivitas masyarakat seperti adanya aliran limbah pertanian seperti aliran abu pembakaran lahan ladang warga dan berkurang nya sumber makanan alami.

Stasiun III. Kemungkinan kualitas air sudah tercemar dikarnakan terdapat beberapa aktipitas masyarakat seperti pembuangan limbah sulingan nilam dan pembuangan sampah, mck dari masyarakat setempat. 
SEMAH : Journal Pengelolaan Sumberdaya Perairan VOL. 1 No. 2

Desember 2017

penghujan, di samping kualitas air yang mendukung untuk habitat hidupnya. Sebaliknya untuk Kepadatan Populasi (KP) terendah terdapat pada beberapa jenis yaitu Baung/murai, Ikan Tali-Tali. Rendahnya Kepadatan Populasi (KP) kedua jenis ikan tersebut di duga karena, lokasi penelitian tidak sesuai dengan habitat hidupnya atau ketidak mampuannya dalam beradaptasi dengan lingkungan yang kemungkinan sudah mulai tercemar.

Untuk Kepadatan Relatif (KR\%) paling tinggi terdapat pada ikan Seperas Puntinus tawerensis (n.sp) sebesar $\quad 0,018000 \%$. Sedangkan Kepadatan Relatif (KR \%) terendah ditemukan pada ikan Baung Murai/Hinur Macrones Wyckii (Blkr), Tali-Tali Acanthopthalmus Kuhli(CV).

Selanjutnya untuk Frekuensi Kehadiran (FK \%) tertinggi atau Absolut di temukan pada 21 jenis ikan yaitu : Baung Macrones nemurus (C.V.), Baung Akar / Baung Kuning Macrones planicep (C.V.), Punti, Tanpang Durian / Ikan Tugok Leiocassic micropogon (Blkr), Juar / Johar Luciosoma sitigerum (C.V.), Semah / Masik Labeobarbus tambra (C.V.), Sebarau Lalas Hampala ampalong (Blkr),

Lampam Puntius schwanefeldi (Blkr), Kepiat Puntius belinka (Blkr), Seluang Pimping Chela oxygastroides (Blkr), Seburuk / Palau Osteochillus kahajanensis (Blkr), Selimang Epalzeorhynchus kallopterus (Blkr), Langli Botia hymenophysa (Blkr), Talitali / Serowot Acanthopthalmus kuhli (C.V.) ,Tilan Mastacembelus maculatus (C.V.), Tiluk Mastacembelus erythrotaenia (de Beaufort \&Brigg, 1962), Semancung / Gigi anjing Choerodon anchorago (Blkr), Batu Choerodon scoenleini (C.V.), masing masing 39 \%. Sebaliknya Frekuensi
ojs.umb-bungo.ac.id/index-php/SEMAHJPSP

ISSN : 2580-0736

Kehadiran (FK\%) terendah di temukan pada beberapa jenis ikan yaitu, Baung Murai / Hinur Macrones Wyckii (Blkr), Tali-Tali Acanthopthalmus Kuhli(cv)

Jika dilihat dari Kriteria penilaian berdasarkan keanekaragaman jenis, Shannon-Wienner, maka Frekuensi Kehadiran (FK\%) Jenis Ikan di perairan Sungai Terap Kabupaten Merangin Propinsi Jambi masuk dalam kategori kehadiran tinggi / absolut.

\section{Penutup}

1. Kesimpulan

Berdasarkan hasil penelitian yang telah dilakukan dapat ditarik beberapa kesimpulan sebagai berikut:

1. Keanekaragaman yang berhasil ditangkap dan diteliti dari Tiga Stasiun di Sungai Terap ditemukan sebanyak 21 jenis Ikan terdiri dari dari:

13 Genus:

1. Baung/Baung (Macrones)

2. Seburuk/Palau (Osteochilus)

3. Punti/Ikana Togok (Leiocassic)

4. Lampam/Lampam (Puntius)

5. Seamah,Masik (Labeobarbus)

6. Seluang Pimping (Chela)

7. Selimang/Seliamang(Epalzeorh ynchus)

8. Langli/Leungli (Botia)

9. Juar/Johar (Luciosoma)

10. Tiluk/Tilan (Mastacembelus)

11. Sngiring/Anak Dukang (Hemipimelodus)

12. Batu,Siben (Choerodon)

13. Semurap/Sapu-Sapu (Homaloptera)

7 Famili :

1. Bang Muni/Hinur (Bagridae)

2. Tilan/Tilan (Mastacembelus)

3. Juar/Johar (Cripnidae)

4. Semancung (Labridae)

5. Tali-Tali/Serowot (Cobitidae)

6. Semurap/Sapu-Sap(Balitoridae) 
SEMAH : Journal Pengelolaan Sumberdaya Perairan VOL. 1 No. 2

Desember 2017

7. Sngiring/Anak Dukan(Ariidae)

4 Ordo:

1. Selimang/Selimang (Ostariophysi)

2. Batu,Siben (Percomorphi)

3. Tiluk/Tilan(Opisthomi)

4. Semurap/Sapu-Sapu (Actinopterygii)

2. Nilai Indeks keanekaragaman jenis ikan pada masing-masing stasiun yakni : Stasiun I enam Kilo meter $(\mathrm{Km})$ dari Desa Muara kearah hulu Sungai Terap sebesar 2,4028 Stasiun II di Desa Muara Pangi sebesasr 1,6687 Stasiun III Desa Muara Pangi sebesar 1,1659. Yang berarti tingkat Keanekaragaman (Hi) jenis Ikan masuk dalam kategori sedang.

3. Kepadatan Populasi tertinggi pada masing-masing Stasiun yakni : Seperas Puntius tawerensis (n.sp) 0,018000 (individu) / $\mathbf{m}^{2}$.

4. Frekuensi Kehadiran tertinggi yakni : Seperas Puntius tawerensis (n.sp) 12860 (individu) / $\mathbf{m}^{2}$. Baung Macrones nemurua $(\mathrm{CV})$ Langli Botia hymenophysa (Blkr) Batu,Siben Choerodon oligantus (Blkr), dan 17 jenis ikan lainnya masing - masing 39\%.

2. Saran

1. Untuk mendapatkan jenis ikan yang lebih banyak dalam penelitian lebih lanjut disarankan agar menggunakan alat tangkap yang lebih bervariasi, Jumlah Stasiun yang lebih banyak dan jangka waktu yang lebih lama.

2. Perlunya kesadaran masyarakat untuk menjaga lingkungan, sehingga perairan Sungai Terap tetap terjaga dan tidak tercemar serta jenis - jenis ikan yang ada diperairan tersebut.
ojs.umb-bungo.ac.id/index-php/SEMAHJPSP

3. Perlu adanya sosialisasi untuk melibatkan masyarakat dari lembaga konservasi, lembaga pendidikan dan pemerintah setempat mengenai pentingnya Sungai Terap Desa Muara Pangi Kecamatan Lembah Masurai Kabupaten Merangin Propinsi Jambi satwa didalamnya khususnya ikan.

4. Bagi petugas lapangan (PPL) kiranya dapat memberikan Penyuluhan kepada masyarakat khususnya Nelayan tentang penting menjaga lingkungan dan menggunakan alat tangkap yang di perbolehkan.

\section{DAFTAR PUSTAKA}

Arrs.Aakti, 2008, Morfologi mengenai tentang bentuk luar suatu organisme. Salah satu cirri yang mudah dilihat dan di ingat.

Budiyono, 2011. Analisis Pengaruh Penambangan Emas dan Pasir Terhadap Kualitas Air dan Keanekaragaman Jenis Ikan di Sungai Batang Bungo Kabupaten Bungo, Tesis Pasca Sarjana Universitas Bung Hatta Padang.

Bps, Tahun 2011 Merangin dalam angka

Dinas Tanaman Pangan dan Hortikultura Kabupaten Merangin, 2012.

Djuhanda, 1981. Jenis ikan dari ordo Percoformes seluruh tubuh nya ditutupi oleh Sisik.

Enim Provinsi Sumatera Selatan. Jurrnal lktiologi Indonesia. 
SEMAH : Journal Pengelolaan Sumberdaya Perairan VOL. 1 No. 2

Desember 2017

Jurusan Biologi Fakultas MIPAUniversitas Sriwijaya

Fithra, RY, Siregar, YI, 2010. Keanekaragaman Ikan Sungai Kampar Inventarisasi Dari Sungai Kampar Kanan, Jurnal ISSN 1978-5283, Alumni Universitas Riau.

Hamidah, A, 2004. Keanekaragaman Jenis Ikan di Sungai Enim Kabupaten Muara

Indra s, dalam Riki p, 2006 Propinsi Jambi memiliki potensi biodipersity berupa keragaman flora dan fauna,.

Jukri, M, Emiyarti, Kamri S. 2013. Keanekaragaman Jenis Ikan di Sungai Lamunde Kecamatan Watubangga Kabupaten Kolaka Provinsi Sulawesi Tenggara. Jurnal ISSN : 2303-3959, Program Studi Manajemen Sumberdaya Perairan FPIK Universitas Haluoleo Kendari

Kamal, E, 2007. Bahan dan Alat penangkapan Ikan. Bung Hatta University Press Padang.

Kottelat, M; A. J. Whitten; S. N. Kartikasari \& S. Wirjoatmojo. 1993. Freshwater of Western Indonesia and Sulawesi. London: Periplus Edition.

Laily, N, 2006, Identifikasi Jenis-Jenis Ikan Teleostei yang tertangkap Nelayan di wilayah Perairan Pesisir Kota Semarang, Skripsi, Fakultas Matematika Dan Ilmu Pengetahuan Alam Universitas Negeri Semarang.
ojs.umb-bungo.ac.id/index-php/SEMAHJPSP

ISSN : 2580-0736

Nybakken, J, W, 1988. Biologi Laut Suatu Pedekatan Ekologis. Gramedia Jakarta.

Odum, E. P, 1993. Dasar-dasar Ekologi. Terjemahan Tjahjono Samingan. Edisi Ketiga. Yogyakarta: Gadjah Mada University Press.

Primack 1998. Keanekaragaman adalah hubungan anatara jumlah jenis dan jumlah individu masing-masing jenis dalam suatu komunitas.

Romimohtarto, K \& S. Juwana, 2001. Biologi Laut. Jakarta: Djambatan.

Saanin, H, 1984, Taksonomi dan Kunci Identifikasi Ikan. Bina Cipta. Jakarta.

Saputra, H, 1988. Membuat dan Membudidayakan Ikan dalam Karamba Jaring Apung. Jakarta; CV. Simplex.

Sudrajat, A, Darti Satiyani, Sudarto, Ketut Sugama dan Murniyati, 2009. Inventarisasi Keragaman Ikan lokal Air Tawar Provinsi Jambi, Dinas Kelautan dan Perikanan Provinsi Jambi, Jambi, Cetakan ke 2, 81 pp.

Siagian, C, 2009. Keanekaragaman dan Kelimpahan Ikan serta Keterkaitannya dengan Kualitas Perairan di Danau Toba Balige Sumatera Utara, Tesis, Sekolah Pascasarjana Universitas Sumatera Utara Medan.

Soemadji. 1995. Zoologi. Jakarta: Depdikbud. Kent, G. C, 1987. Comparative Anatomy of The Vertebrates. St. Louis-Toronto- 
SEMAH : Journal Pengelolaan Sumberdaya Perairan VOL. 1 No. 2

Desember 2017

Santa Clara: Time Mirror/ Mosby College Publishing.

Soeseno, S, 1984. Dasar-dasar Perikanan Umum. Jakarta: CV. Yasaguna.

Soeseno, S, 1988. Budidaya Ikan dan Udang dalam Tambak. Jakarta: Gramedia.

Shahab, A. Z, 1986. Telaah Perbandingan Sebaran Burayak Planktonik Terutama Avertebrata Bentik dan Goba-Goba Pulau Pari pada bulan SeptemberDesember 1982. Jakarta: PT. Wira Utama Pramesti.

Sukiya, 2003. Biologi Vertebrata. Yogyakarta: Biologi FMIPA UNY.

Suhara A, 2009. Sejarah Propinsi Jambi. CV Aksara Media Jambi.

Saputra, FM, 2004. Daerah Aliran Sungai Batang Hari, Makalah-pdf Web:ttp://penataanruang.pu.go.id/t a/Lapak04/P3DasBatangharAkhir. html disakses tanggal 24 Agustus 2013, pukul 08.41 WIB.

Upriadi ,2004,menurut Kamus Besar Bahasa Indonesia klasifikasi adalah penyusunan bersistem dalam kelompok atau golongan menurut kaidah atau standar yang ditetapkan.

Universitas Muara Bungo, 2011. Panduan Teknis Penulisan Skripsi.

Padoli, 2013. Studi Keanekaragaman Marozoobentos sebagai Bio Indikator Kualitas Perairan Danau Babeko Kabupaten Bungo,
ojs.umb-bungo.ac.id/index-php/SEMAHJPSP

Skripsi, Strata Satu Fakultas Perikanan Jurusan Pemanpaatan Sumberdaya Perikanan Universitas Muara Bungo.

Wooton, J, 1991. Ecology of Teleost Fishes. New York: Chapman \& Hall.

Yustina, 2001. Keaneka Ragaman Jenis Ikan Disepanjang Sungai Rangau, Riau, Sumatera, Journal Nature

http//jambidalamangka//pdf disakses tanggal 24 Agustus 2013, pukul 08.41 WIB.

http//jambi Inra Syaputra 2006. memiliki potensi bio-diversiti berupa keragaman flora dan faun,yang sangat kaya,seperti umumnya wilayaah pantai timur Sumatra. 
SEMAH : Journal Pengelolaan Sumberdaya Perairan

VOL. 1 No. 2

Desember 2017
ojs.umb-bungo.ac.id/index-php/SEMAHJPSP

ISSN : 2580-0736 